\title{
Loomakaitse ja inimeste suhtumine loomadesse 1930. aastate Eestis
}

Loone Ots

\begin{abstract}
Teesid
Artiklis vaadeldakse loomakaitse ajaloo algust maailmas ja Eestis ning vastavat eestikeelset kirjandust. Edasi uuritakse loomakaitseliikumist 1930. aastate teisel poolel, kasutades allikana Eesti Loomakaitsjate Liidu häälekandjat ajakirja Eesti Loomasõber. Ajakirja materjalide põhjal käsitletakse loomakaitsega seotud seadusandlust, loomakaitse ideoloogilisi aluseid ning loomade väärkohtlemise juhtumeid maal ja linnas. Püütakse leida, mille poolest erineb maa- ja linnarahva suhtumine loomadesse. Lõpuks esitatakse kolm näidet erinevate loomakaitse seltside tööst Tallinnas ning maakonnakeskustes Viljandis ja Petseris.
\end{abstract}

Märksõnad: 1930. aastad, Eesti ajakirjanduslugu, Eesti Loomakaitsjate Liit, Eesti Loomasõber, kultuur, kultuurilugu, loomakaitse

\section{Sissejuhatuseks}

\section{Loomakaitse algusajad maailmas}

Loomakaitse ajalugu maailmas ulatub ametlikult aastasse 1824, kui Londonis asutati Loomadevastase Julmuse Ennetamise Selts (Royal Society for the Prevention of Cruelty to Animals, RSPCA). Selts sai alguse Richard Martini 1822. aastal Suurbritannia parlamendile esitatud ettepanekust kehtestada seadus, mis kaitseks kariloomi, hobuseid ja lambaid (keda toona kariloomadeks ei peetud) inimese vägivalla eest. Richard Martin, hüüdnimega Inimlik Dick, oli kaks aastat hiljem üks seltsi 22 asutajaliikmest.

Noil aastail olid loomakaitsjad üldsuse silmis vaid veidrikud, loomi aga käsitleti lihtsalt kui toitu, meelelahutust või spordivahendeid. Loomakaitseliikumise esimesed aastad kulusidki avalikkuse suhtumise muutmisele. 1832. aastaks oli loomakaitse juba nii tugeva kandepinnaga, et Briti kohus määras 181 inimesele vanglakaristuse loomade julma kohtlemise eest. 1840. aastal lubas kuninganna Victoria kasutada seltsi nimes sõna kuninglik. Tekkisid allseltsid nii Briti saartel kui ka mujal Euroopas. Loomakaitse hak- 
Loone Ots

kas levima üle maailma. 1860. aastail polnud loomakaitseselts enam haruldus mis tahes Euroopa alal.

\section{Loomakaitse algus eesti keeleala kubermangudes}

Tsaari-Venemaa Liivimaa kubermangus, kuhu kuulus ka praegune Lõuna-Eesti, asutati esimene loomakaitseselts 1861. aastal pealinnas Riias ja selle nimi oli Loomade Piinamise Vastu Võitlemise Selts. 1877. aastal muudeti ühenduse nimi Riia Loomade Varjupaiga Daamide Komiteeks. Seltsi asutajaliikmed esindasid muidugi kohalikku ülemkihti ehk baltisakslasi.

Esimene tänini säilinud eestikeelne loomakaitse-alane trükis pärineb kolmkümmend aastat hilisemast ajast: 1891. aastal avaldasid Tallinna organiseerunud loomakaitsjad neljaleheküljelise vihiku Tallinna "Elajakaitse-Seltsi"lennuleht Eestirahvale (Tallinna... 1891; siin ja edaspidi algne kirjapilt muutmata, loetavuse lihtsustamiseks on korrigeeritud vaid interpunktsiooni ja w-täht asendatud vga). 1901. aastast pärineb järgmine oluline maakeelne üllitis. Sedapuhku on tegemist väga laia kandepinnaga: sihtrühm on külakoolide õpilased üle kahe kubermangu (eeldamisi on sama jutlus kasutusel ka Harkovi piiskopkonnale alluvates venekeelsetes kubermangudes, vahest mujalgi). $31 \mathrm{lk}$ paksune Riias ilmunud raamatuke kannab ajastule iseloomulikult pikka pealkirja Õpetus lastele, kes külakoolides käivad: Loomadega peab tasaselt ja haledameeleliselt ümber käidama. Raamat on kakskeelne (vene ja eesti), autoriks Harkovi linna ülempiiskop kõrgestipühitsetud Ambrosi. Tekst esitab loomade väärkohtlemise tüüpjuhtumeid (hobuste jt kariloomade armuta peksmine), taunides inimese käitumist tema hoolde usaldatud eluga. Piiskop tõdeb, et

[---] haritud inimesed astuvad selle südameta inimeste paha viisi vastu välja: nad asutavad "loomade kaitsmise" seltsisi, heidavad ennast nende liikmeteks ja teevad oma kohuseks tarvilisel korral tigedaid inimesi nende metsiku tegudes takista$d a$ (Ambrosi 1901: 5).

Autor viitab Piibli käskudele armastada loomi kui jumala loodut.

Issand Jumal lõi maailma ja ehtis teda arvuta loomade hulgaga; igaüks neist kannab enese peal Jumala kõigekõrgema helduse, võimsuse ja tarkuse märki (Ambrosi 1991: 9). 
Ta osundab õigesti, kuidas lapse kasvatus teda kas heaks ja südamlikuks või vastupidi, kurjaks ning julmaks muudab:

Väga raske on [---] neid (häid) tundmusi niisugustes lastes istutada, kes ise kiskuja ja metsiku loomade sarnaseks on saanud (Ambrosi 1991: 21).

Vaheldumisi piiblitsitaatidega tutvustatakse kaasakiskuvalt loomariigi korraldust ja erinevate elusolendite väärtusi (mesilaste sümmeetria-, lindude suunataju). Samas selgitab raamat, et inimesel on õigus looma oma vajadusteks või enesekaitseks tappa. Kuid selle üle mõistab ülempiiskop kurvastada juba enam kui sada aastat tagasi:

[---] aga siin peab ta mõistlik olema, mõõtu pidama ja vaatama, et mitte noored ja inimese kasuta loomad surmatud ei saaks. Paraku, on nüüdsel ajal rikkuse ja toreduse himu läbi iseäranis ilusa ja kalli metsloomade surmamine nii suureks läinud, et mõndagi sugu täieline hävitamine ootab (Ambrosi 1991: 21).

Naastes koduloomade kohtlemise küsimuse juurde, küsib ta retooriliselt:

Eks pole meie kohus neid Jumala armu andeid, mis Tema meile meie maapealse elu kergituseks annab, tänuga vastu võtta ja loomade vastu, kelle läbi meie kõik seda saame, tähelepanelikud, hoolsad, õiglased ja, nenda ütleda, sõbralised olla? (Ambrosi 1991: 23).

Ambrosi näitab kujukalt, kuidas vägivald loomade vastu äratab lastes alguses õudu, pikapeale muutub aga harjumuseks ning kuidas seeläbi kasvab hinges vägivald ja ükskõikne suhtumine vägivalla ilminguisse, mis võib olla suunatud mitte enam loomade, vaid juba inimeste vastu. Ülempiiskop Ambrosi ütleb kokkuvõtvalt:

Mõtelge järele, kas võib keegi inimest äratappa, kui ta ei ole harjunud loomagi ilmaasjata surmama, ehk meelega kahjuta putukast surnuks tallama üksi sellepärast, et temal jõudu on nõrga loomakese elu ära võtta? [---] meie ei ole seda elu temale annud, ei või ka tagasi anda, kui ära võtame. Kes nii mõtleb 


\section{Loone Ots}

ja tunneb, ei see tee oma ligimesele ülekohut [---] (Ambrosi 1991: 31).

Kas ja kuivõrd sellest kasu oli, ei oska tagantjärele öelda. Tallinna Ülikooli Akadeemilises Raamatukogus säilinud ainueksemplar oli lahti lõikamata... Igal juhul on loomade väärkohtlemine nagu Inglismaa näiteski seotud eeskätt julmusega koduloomade vastu. Seega võib teha üldistuse: inimese suhtumine koduloomadesse, praeguses õigusruumis põllumajandusloomadesse, oli ääretult inimkeskne ja looma alavääristav - loom kui tulevane toit või kui sõiduvahend, äärmisel juhul sotsiaalse staatuse prestiižne indikaator, kuid mitte partner, isegi mitte elus olevus, kes võis kannatada valu, nälja või külma tõttu.

Ometi oli loomakaitsel ühiskonnas järjest rohkem kõlapinda. 1920. aastail avaldab Tartu Eesti Loomakaitse Ühing lendlehe (Mieler 1920ndad), milles seostab loomakaitse mitte ainult inimese, vaid ka taimeriigiga. Artikkel "Kas vajavad loomad ja taimed inimese kaitset?" kinnitab juba esimeses lauses, et selle peale vastab küll igaüks jaatavalt. Tegelikkus on aga teistsugune. Jälle tuuakse esimese näitena hobuste julm kohtlemine, teine negatiivne näide on aga liigagi tänapäevane: poisikesed pü̈̈avad tänaval väikseid linde, talvikuid, ja kõrvetavad neil tiivad ära! Nii nagu lapsed ka puid rikuvad ja liigselt lilli nopivad. Lendlehe väljaandja nõuab, rõhutades loodusõpetuse õpetajate osa laste hinge harimisel:

Mitte kurjus ei ole siin pääpõhjuseks, vaid pääliskaudsus, omamise tung ja vale teadmine, et see temal lubatav. [---] “Aukartus elu vastu!” olgu meie hü̈̈dsõna! Ärgem hävitagem mõttetult elu! (Mieler 1920ndad).

Selles näites viidatakse juba "tänavale", linnakeskkonnale. Siit hargneb hulk intrigeerivaid küsimusi. Missugused olid 1930. aastate eestlase loomadega seotud suhtumised ja hoiakud? Millised loomad olid "head" ja millised "pahad", milliseid peeti "kasulikeks", milliseid mitte? Milles seisnes eestlase arvates looma kasulikkus, kahjulikkus jne? Hoiakuid manifesteerivad teod. Mida loomadega teiste nähes teha võis ja mida ei tohtinud, s.t, mida ühiskond aktsepteeris ja mida mitte? Kas oli erinevusi suhtumises nt koera ja hobusesse või hunti ja nirki? Ja veel üks oluline moment: kas oli erinevusi maa- ja linnarahva suhtumises? Kui jah, siis mis neid tingis? 
Loone Ots

\section{Loomadest ja loomakaitsest Eestis 1930. aastail}

\section{Pisut statistikat}

1934. aasta rahvaloenduse andmeil elas Eestis 1061000 inimest. Nendest elas linnades 342400 ja maal 718900 inimest. Linnarahvastiku osatähtsus oli $32,2 \%$. Võrreldes 1922 . aastaga oli nende osa võrreldes maarahvaga kasvanud 4\%. Rahvastiku tihedus ruutkilomeetril oli 23,5 inimest (Noor 1993: 94).

Loomade kohta on sama aasta võrdlusandmed järgmised. Eestis oli 211500 hobust, 676300 veist (neist lehmi 406 700), 552100 lammast, 281700 sigaja 995300 kodulindu. Kokku oli Eestis 2516500 põllumajanduslooma ja lihtne arvutus näitab, et neid oli ruutkilomeetri kohta umbes 66 , niisiis 2,8 põllumajanduslooma ühe inimese kohta (Noor 1993: 297).

\section{Loomakaitsjate häälekandja: ajakiri Eesti Loomasõber}

Ajakiri Eesti Loomasõber (edaspidi ka ELS) oli järg aastatel 1931-1934 ebaregulaarselt ilmunud Loomakaitsjale ning järgis nimetatud ajakirja formaati ja teemaringi. Eesti Loomasõber ilmus Tallinnas Eesti Loomakaitse Liidu häälekandjana aastatel 19351939, algul kuus numbrit aastas, 1937. aastast alates neli, 1938. aastal tuli trükist vaid kaks numbrit ja 1939. aastal kõigest üks - kokku 26 numbrit, millest mõned olid kaksik- või mitmiknumbrid.

1935. aasta alguses ühines ELSiga Tartus kirjastatud Loomakaitse Ajakiri. Algul oli ajakiri koos kaantega $20 \mathrm{lk}$ paksune, millest 4-5 lk oli maksulist reklaami, sisule jäi seega umbes 15 lehekülge. Kahel viimasel aastal vähenes ajakirja maht: 1938. aastal oli see 18 ja 1939. aastal $16 \mathrm{lk}$.

Rahalistel põhjustel, aga ka lootuses leida laiemat kandepinda, liideti ELS 1939. aastal Loodushoiu- ja Turismi-Instituudi looduskaitseajakirjaga Loodushoid ja Turism, arvestades, et looduskaitse sisaldab ju ka loomakaitse põhimõtet.

Et ELSis avaldatud kirjutised on sageli anonüüümsed ja nende autoreid võib ainult aimata nt signeeringu nimetähtede järgi, on viitamisel enamasti kasutatud ainult ajakirja vastava numbri ja selle lehekülje või lehekülgede esitamist. 


\section{Loone Ots}

\section{Loomakaitse ideoloogilisi aluseid}

Kuidas loomi kaitsti? 1935. aastal oli Eestis 22 loomakaitseseltsi ja -ühingut, kuhu kuulus 4500 täiskasvanud liiget. Neist 18 oli 1929. aastal ühinenud Eesti Loomakaitsjate Liiduks (edaspidi ka ELL). Loomakaitse põhimõtetest on ehk tähtsaim rakendusliku tegevuse filosoofiline alus. ELL lähtub Genfis asuva rahvusvahelise loomakaitse büroo sätestatud tegutsemispõhimõtetest, propageerides tegevuste mitmekülgsust ja loomakaitse eri aspektide integratsiooni.

Uudne lähenemine taunib teoloogide seniseid seisukohti, mille järgi loomadel polevat õigusi ja nad peavadki täielikult sõltuma inimeste tahtest. Tsiteerin rahvusvahelise büroo toonast presidenti Louise Lind-af-Hagebyd:

Fü̈üsiliselt inimene lõikab kurjust, mida ta külvab. [---] Inimolevuste kaitse ja loomade kaitse on üks ja seesama (Lind-afHageby 1935).

Inimorjuse ja lastekaubanduse kaotamine on ideoloogiliselt lähedalt seotud hüljeste kaitsmise ja kaevandushobuste töötingimuste parandamisega. Vastavalt võitleb ELL nt loomkatsete vastu, kuid mõistab rangelt hukka ka putukate püüdmise ja surmamise õppeotstarbel, lastele liblikavõrkude kinkimise jms (ELS 4/1935: 67). Piinamine ja asjatu surmamine on ülekohus ja toorus ka lapse enda vastu, [kui] seda lubada, võtab nimetatud numbri juhtkiri teema kokku. Veel refereeriksin lõiku A. M. (A. Matto?) artiklist "Kuhu suundub inimsugu?" alapealkirjaga "Loomakaitse ülesandeks on inimsoo hinge äratamine":

Halastamatu ümberkäimine loomadega, nende elu-ja õnneoiguse mitte tunnistamine on ainult osa peaeksimustest inimsuse osas tähtsa eraldamisest tähtsusetust. Lapsele õpetamine, et tähtsam on olla hea kui tark, on kogu inimsuse kaaluvaim elutõde. Teoorias on inimese vendlus tunnustatud mõnes olukorras usu-ja kõlblusõpetajate poolt. On aga olemas kogu selle maakera loojuse vendlus (Matto 1935).

ELLi esimees Bernhard Methusalem usub, et 
[---] loomakaitsja inimene on inimtüübi ideaal. Inimene, kes ei tee halba loomale, ei tee seda ka oma kaasinimesele [---] meie rahvas oma hingelaadilt on kaine ja loomasõbralik ning tema iseloomus puudub üldse kalduvus toorusteks ja loomapiinamiseks. Üksikud loomadega halvasti käitumise ja piinamise juhused tulevad ette eranditena ning needki rohkem alateadlikult, mistõttu peaksivad täiel määral välditavad ja parandatavad olema vastava loomakaitselise selgitustööga ilma igasuguste sanktsioonide tarvitamiseta (Methusalem 1936: 127).

Paraku näitab elu, et B. Methusalemi idealistlik arvamus ei pidanud paika ja loomade turvalisust tuli tagada just nimelt sanktsioonide ja seaduse jõu abil.

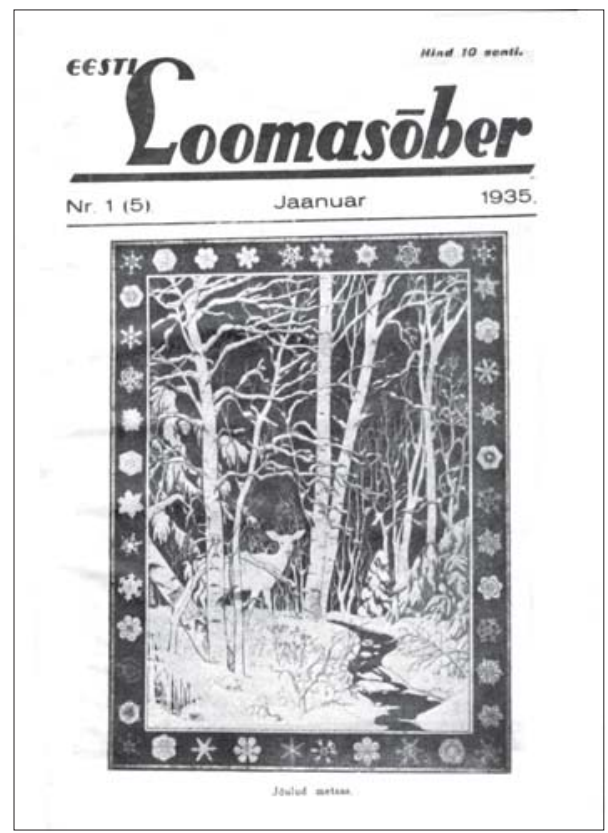

Joonis 1. Eesti Loomasõbra avanumber. 
Loone Ots

\section{0. aastate seadusandlus loomakaitsest}

ELLi juhatuse liige Arnold Kattemaa nendib, et

[---] ei ole üheski kultuurriigis veel välja töötatud seadusi, mis kindlustaks loomale täielikult tema õigused (Kattemaa 1935: 47).

Eesti Vabariigis kehtivas kriminaalseadustikus ja jahiseaduses käsitleti loomapiinamist ainult mõnes harvas paragrahvis. Põhiliselt mõisteti loomade piinajad süüdi kriminaalseadustiku § 276 alusel (Loomade asjata piinamine on karistatav). Kaudselt toetasid loomakaitse ideed veel kriminaalseadustiku § 244-249, jahiseaduse § 2223 ning tapamajade ja liha järelevaatuse seaduse $§ 23$. Loomade vedu raudteel reguleerib loomade ja loomatoorsaaduste veomäärus (Riigi Teataja 149, 1925, muutustega Riigi Teataja 103, 1931), määrust refereerib ELLi juhatuse liige, vandeadvokaat B. Methusalem 1936. aasta Eesti Loomasõbra avanumbris. Lõpuks võiks õigusaktina käsitleda ka 1993. aasta Haridus- ja Sotsiaalministeeriumi Teatajas nr 11 avaldatud üleskutset luteri, õigeusu ja kõigi teiste usuühingute juhtidele paluda käsitleda loomakaitse aadet loomakaitsepäevale ligemal pühapäeval peetavas jutluses (vt ka ELS 5/1935: 98).

Esimest "päris" loomakaitseseaduse kava hakkab ELL rahvusvahelisi eeskujusid järgides välja töötama 1935. aastal (vt ELS 6/ 1935: 108-112). Ette rutates võib öelda, et eelnõu võttis vastu nii ELLi juhatus kui 1936. aasta Tartu VIII loomakaitse kongress ja see esitati riigivanemale 1937. aasta alguses.

Seni püüdis Eesti Loomakaitse Liit, et iga maakond ja linn kehtestaks kohaliku loomakaitsealase sundmääruse. Kahjuks polnud omavalitsuste loomakaitseline teadlikkus teab kui kõrge ja 1935. aastal kehtisid loomakaitse sundmäärused ainult kahes maakonnas Valgamaal (vastu võetud 1931) ja Pärnumaal (vastu võetud 1932) ning järgmistes linnades: Tallinnas (1922, muudetud 1929), Tartus (1928), Nõmmel (1929), Rakveres (1929), Narvas (1930), Valgas (1930), Paides, Võrus, Haapsalus, Petseris (kõik 1931) ja Tõrvas (1933). Eesti Loomakaitse Liidu pidev pealekäimine tingis sundmääruse vastuvõtmise Läänemaal (1935), läbirääkimised jätkusid Viru maavalitsusega. 1935. aastal tegi ELL politseivalitsusele ettepaneku võimaldada politseikoolile mõned ainetunnid loomakaitsealase seadusandlusega tutvumiseks. Ettepaneku tagajärjed ei ole teada. 
Loone Ots

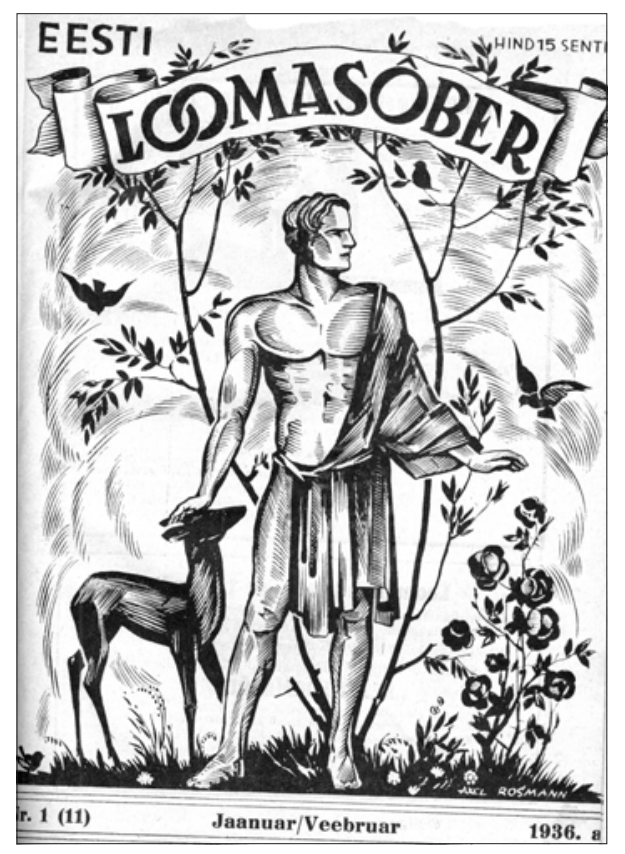

Joonis 2. Nagu paljusid 1930. aastate ajakirju, nii kaunistasid ka Eesti Loomasõbra numbrite kaasi maitsekad puulõiked.

Seega sai seaduse jõudu rakendada loomapiinajate vastu enamasti ainult siis, kui nad sõitsid nt Tartu maakonnast Tartu linna ja sooritasid oma väärteod seal. Veenmaks ühiskonda loomi kaitsvate seaduse vajalikkuses, kirjeldas ELS igas numbris räigeid loomade väärkohtlemise juhtumeid, mis olid koondatud rubriiki "Loomakaitseliikumise uudismaa".

\section{Loomade mured linnas ja maal ajakirja Eesti Loomasõber pilgu läbi}

\section{"Loomakaitseliikumise uudismaa"}

Rubriik "Loomakaitseliikumise uudismaa" on ajakirjas loomakaitse edendamise seisukohalt kahtlemata kõige vajalikum: šoki- 


\section{Loone Ots}

teraapia kinnistub hästi emotsionaalses mälus, seda räägitakse edasi ja peetakse meeles. Halva uudise skeem on üldjuhul sama: ELS esitab harilikult negatiivse näite, seejärel aga teatab, et inimesed on pöördunud kohaliku loomakaitse (või politsei) poole, kurjategija on võetud vastutusele, tihti on karistuski juba määratud. Teadetes kasutatakse peaaegu alati täisnimesid. Kurvastav on, et negatiivseid näiteid jätkub igasse numbrisse.

Erinevalt tänasest kannatasid julmuse all enamasti põllumajandusloomad. Kõige rohkem on teateid hobuste ja veiste väärkohtlemisest. Esimesel juhul looma peksti, ka nt kiviga pähe, hoiti külmaga õues, jäeti teele või kraavi maha, ei ravitud tema haigusi, sunniti vedama üle jõu käivat koormat, piitsapiugu põimiti naelu või okastraati. Tartus lõikasid kurjategijad ära sissesõiduhoovides seisvate hobuste sabasid, sageli koos naha ja sabaluutükiga. Viljandi parisnikud jootsid hobust denaturaadiga, kuni ta suri, jne. Veiste väärkohtlemisel oli põhirõhk samuti peksul, peamiselt teel tapamajja; juttu on ka julmustest loomade vedamisel. Loomade pidamine lautades oli kohati "ebainimlik" (külm, vesi põrandal, tuuletõmbus). Korduvalt on teateid põlenguist, mille tõttu hukkus suuremal arvul loomi. Loom võis elu kaotada ka auto, bussi või rongi all. Sugugi haruldane polnud looma vigastamine või tapmine kättemaksuks tema peremehele. Mõned eredamad ja ühtlasi tüüpilisemad näited:

Tähtvere valla elanik Bernhard Kunda sõitis nelja hobusega Tartu. Ta jättis hobused külma ilmaga katmatult tänavale. Hobused värisesid külma käes ja lakkusid janu pärast maast lund. Lõpuks loomad äratasid kordniku tähelepanu, kes viis hobused sissesõiduhoovi. Öövahtide seletuse järgi seisid hobused tänaval 4-5 tundi järelevalveta. Bernhard Kunda ise viibis selle aja jooksul Oru restoraanis ja lõbutses. Loomapiinaja võeti kohtulikule vastutusele. Jaoskonnakohtunik noomis Bernhard Kundat, et loomade vastu ei või ikka olla nii südameta, ja karistas teda 4-ööpäevase arestiga või 20-kroonise rahatrahviga (ELS 3/1935: 33).

Kalavenelane Ivan Kalnin oli Raasiku jaoskonnakohtuniku juures vastust andmas hobusepiinamise pärast. Ta on kasutanud nimelt kalaveol katkise kaelaga ja vigast hobust. Mees end süüdi ei tunnista - ta käinud ju loomaarsti juures ja toonud ka arstimi. 
- Kas kael oli katki? küsib kohtunik.

- Natuke oli paistes sedelga alt, õige natuke... Mustvees lasksin lõigata ja siis tuli haavast õige natuke kollast vett.

- Nii siis sõitsite enne veel pikad maad läbi, kui läksite arsti juurde?

- No-jaa, mul oli väike koorem peal. Oli vast viisteist puudakalu.

- Hobusele piina teie siis ei sünnitanud?

- E-ei, on venelane kindel.

Politsei protokoll aga räägib, et hobuse kael olnud õige suurelt katki ja verine. Sama tõendab ka ülekuulatud tunnistaja. Kohus määras Kalninile 15 krooni trahvi või maksujõuetusel 3 ööpäevaks aresti (ELS 2/1936: 165).

Peipsi piirkond oli loomade kohtlemise seisukohalt üldse üks õõvastav paik, näidete hulgast valisin veel järgmise:

Mustvees ja selle ümbruses tuleb tihti ette julmemaid loomapiinamisi, mida võib ainult ette kujutada. Nii on seal levinud kombeks, et vanadel, tapmisele määratud hobustel nülitakse nahk seljast elusalt, ilma looma enne surmamata. Põhjustatakse seda äärmist toorust seega, et elusa looma seljast tuleb nahk hoopis kergemini ära (ELS 3/1935: 54).

Erinevalt tavapärasest ei süüdistatud selles loos kedagi konkreetselt ega räägitud vastumeetmetest ja karistustest.

Edasi mõned näited sarvloomadest.

Loomapiinamise pärast tehti protokoll Kolga vallas Aru külas elutseva loomakaupleja Joosep Muru peale, kes vedas kergeveoautol loomi Tallinna tapamajja. Auto, millesse oli paigutatud kaks sarvlooma, oli nii madal, et loomad pidid seisma harkisjalu, kusjuures nende seljad olid surutud kõvasti vastu autokatuse raudvarvu ja küljed vastu autoseinu. Loomad toodi Kuusalust, mis asub Tallinnast $45 \mathrm{~km}$ kaugusel (ELS 4/1935: 72).

7. mail s.a. umbes keskpäeva ajal toimetasid Tartu lihunik J. T. (erandlikult nime ei avaldata, ju ta oli kohalikus kontekstis mõjukas mees - L.O.) ja tema abikaasa L. Võru tänavat mööda üht lehma tapamajja. Jõudes parajasti apostli- 


\section{Loone Ots}

ku õigeusu surnuaia väravate kohale, kukkus lehm tänavale ja ei jõudnud enam üles tõusta. Sellepeale said T.-d lehma peale vihaseks ja hakkasid teda peksma jämeda kepiga ja jalgadega. Kui lehm peksmisest hoolimata ei jõudnud üles tõusta, murdis J. T. lehma kaelast ja sabast, et valuga sundida looma üles tõusma. Kuid seegi ei aidanud, lehm üles ei tõusnud ja lihunikkudel tuli kohale tuua hobune vankriga, peksetud loom vankrile asetada ja tapamajja toimetada. Metsikult loomaga ümberkäimisest teatasid pealtnägijad Tartu Eesti Loomakaitse Ühingu esimehele härra J. Michelsonile, kelle korraldusel koostati loomapiinajatele J. ja L. T.le protokollid ning nad kutsuti kohtusse vastust andma. Kaebelaused kohtus end sü̈̈di ei tunnistanud. Kohus aga leidis lihunikkude sü̈̈teo küllalt tõendatud olevat ja karistas J. T. 30-kroonise rahatrahviga või 8-ööpäevase arestiga, L. T. 20-kroonise rahatrahviga või 5-ööpäevase arestiga (ELS 5/1935: 95).

Halvasti koheldi ka kodulinde. 1937. aasta Eesti Loomasõbra 4. numbris leidub tendentsliku pealkirjaga uudis "Juuditar piinas kanu", mille järgi oli süüdlane korvis olnud viie elusa linnu peale ladunud kogu turult ostetud kraami:

Teiste turuliste poolt juhiti Ida Rogovsky tähelepanu sellele, et kanad korvipõhjas pakkide all piina tunnevad ja valu pärast karjuvad, kuid Rogovsky ei mõelnudki lindude päästmisele, vaid seletas, et tapmisele lähevad need niikuinii, mis neist veel haletseda.

Rakvere jaoskonnakohtunik karistas Ida Rogovskyt 15-kroonise rahatrahviga või 5-ööbase [ööpäevase] arestiga, lindude piinamise pärast.

Kanalihale maiad juudid peaksid sellest õpetust võtma ning linde ikkagi "haletsema", ka surmaminevaid. Kes ei haletse looma või lindu, ega see, teadagi, hooli ka inimesest. Revideeritagu omi vaateid - nii loomadega kui inimestega käitumisel (ELS 4/1937: 317).

Nagu eeltoodud kalavenelase näites, oli ka nüüd ksenofoobidel hea põhjus osatada; antud juhul on neil põhimõtteliselt õigus, kuid nagu teisalt näha, piinasid loomi ka eestlased ise. 
Tänu headele inimestele jõudis loomadega toorutsemine tihti kohtukulli ette. Samuti ei saa üle hinnata loomakaitsjate juurutatud ennetavaid abinõusid ja lihtsalt teadmist, et on olemas kontroll loomade pidamise ja kohtlemise üle. Kevaditi avaldas loomakaitse ajakirjanduses ringkirja, milles palus omanikke lõigata tagasi loomade talvel liiga pikaks kasvanud sõrad ja sarved, mis muidu kasvavad lihasse ja takistavad nägemist või käimist. Märtsis 1937 sooritas linnavalitsuse komisjon Nõmmel hobuste ja veoriistade ülevaatuse. Võrreldes eelmiste aastatega, kus kuni 50\% hobuseid ja riistu ei vastanud loomakaitse sundmääruse nõuetele, leiti rikkumisi ainult $2 \%$ - selge märk loomakaitse töö tõhususest.

Koduloomadega võrreldes on teateid vägivallast metsaelanike vastu vähem, kuid neidki leidub paras hulk. Mitu teadet on salaküttidest. Metsloomi püüti, kasutades nt kitse kättesaamiseks rebaseraudu; salaküttisid nii mehed kui ka naised. Kehtiv jahiseadus lubas salakütte karmilt karistada. Käreveres emapõdra tapnud salakütt Karl Jurak läks kuuks ajaks vangi, lisaks pidi ta maksma tervelt tuhat krooni trahvi. Kõige kurvem metsloomaga juhtunud lugu on kirjas 1937. aasta Eesti Loomasõbra 4. numbris. See algab isegi veidi halenaljakalt:

Sinalepa valla Tuuru külas elutsev 38-aastane August Rääli oli kolm kuud tagasi külapoistega joobnud olekus sattunud vaidlusse ja kihlveo tagajärjel sõi mees elusa konna ning tahtis otsa peale teha ka elusale siilile, kuid pidi oma kavatsusest siili teravate okaste tôttu loobuma (ELS 4/1937: 317).

Tegelikult oli asi aga naljast kaugel, sest:

Siili jalad aga oli mees siiski maha hammustanud ja ära söönud. Asjale sai jälile kohaliku rajooni konstaabel, kes mehele loomapiinamise pärast koostas protokolli. Nü̈̈d seisiski "vägimees" Haapsalu jaoskonnakohtuniku ees oma teo eest vastust andmas. Ta võttis oma jõhkra-toore sü̈̈ puhtsüdamlikult omaks, seletades, et sooritanud konnasöömise joobnud olekus. Jaoskonnakohtunik karistas A. Räälit elusa konna söömise eest 35-kroonise rahatrahviga või selle mittetasumisel 10-ööbase [ööpäevase] arestiga (ELS 4/1937: 317). 


\section{Loone Ots}

Rääkides loomade olukorrast linnakeskkonnas, tuleb meeles pidada, et tollane linlane elas linnas enamasti alles esimest põlve. Seega oli tema arusaam loomade pidamisest ja kohtlemisest veel suhteliselt "maine". Linnades loomakaitseni jõudnud loomade väärkohtlemise juhtumid erinevad maakohtade omadest selle poolest, et kui maal oli hoolimatus või julmus kultuuripõhine (looma vaadeldi kui toitu või kui töövahendit, igal juhul tundmusteta instrumenti, kelle valuaistingud olid olulised just inimese heaks tehtava töö produktiivsuse tõstmise seisukohalt), siis linnas esines rohkem vaimset vägivalda loomade suhtes, mis oli sageli tingitud meedias pakutava mehaanilisest reprodutseerimisest. Võib tuua järgmisi näiteid. Tollal ülimenukate Tarzani-filmide puhul ei mäletanud paljud nende humaanset, loomi väärtustavat sisu, vaid tõlgendasid "džungliseadusi" omal kombel. Kuressaares sundisid poisikesed naabri õuekoera tarzanimängus lõvi olema, käskisid loomal vastu tahtmist lossivallile ronida ja ründasid teda:

Neid oli ainult pool tosinat, kuid kerge vaevaga saadi lõvist jagu, seoti ta puu külge ja tehti poolpehmeks, nii et tal ikka veidi hinge jäi veel sisse. Kuid Tarzan teatavasti ei võidelnud mitte üksi kuivamaa kiskjatega, vaid oli ka vee-elukate vastu kange mees. Seepärast noored metsmehed [---] tassisid pooluimase "lovvi" vallikraavi vette ja sundisid teda seal mängima merehobust.

Seal nägi noorte kangelaste tempu salkkond noori tütarlapsi, kes võtsid poolsurnud lõvi ja merehobuse asetäitja Tarzanite käest ära. Loom oli sellest mängust päritud väsimust puhkanud mitu päeva.

Ka noortele dsunglisangareile ei lõppenud asi just ilma pahandusteta. Asjast sai kuulda loomakaitse ühing, kes informeeris sündmusest kooli juhtkonda ja see omakorda tarzanite vanemaid. Nii et oma väikesed järeldused tuli asjast teha ka vaprail metsmeestel (ELS 4/1936: 202).

Tänapäeval nii levinud loomade pilamine, nende vägivaldne "inimlikustamine" hakkas juba 1930. aastate lõpul võrseid ajama. Nii teatab 1937. aasta Eesti Loomasõbra 2. number:

Tallinna linna uues, $n$.-n. Vismari pargis on all orus Toompea veerul võrkudega piiratud aiaosa, kus asub paar noort metskitse. Kahjuks ei osata aga meil alati lugu pidada publi- 
kule võimaldatud nägemisväärsustest. Nii näiteks narritakse läbi võrgu noori loomi ja hirmutatakse neid. On saadud hakkama koguni seesuguse ulakliku teoga, et noorte loomade suhu on topitud põlevaid paberossiotse. Kaaskodanikel peaks olema sündsustunnet ka loomade vastu [---] (ELS 2/ 1937: 282).

Esines ka lihtsalt loomade kiusamist väiksemas mastaabis, näiteks tuvide toitmise juhtum Tartu raekoja platsil:

[---] niipea kui daam tuvidele toidu maha raputanud oli ning sajad tuvid tihedalt üksteise kõrval lõunasöögile olid asunud, keegi lillas ülikonnas isik sihilikult läbi tuide parve edasi-tagasi sammuma hakkas, tahtes silmnähtavalt tuvisid surnuks tallata. Tuvid pidid hirmuga ära lendama. Niipea kui nad uuesti sööma laskusid, kordus toores tegu uuesti. Sealjuures ei kohkunud lillas ülikonnas isik isegi daami toorelt eest ära tõukamast, kui viimane mehele takistuseks ette astus, ning palus tuvide söötmist mitte takistada. Ning seda ei teinud mitte mõni poisikene, purjus ega puuduliku mõistusega inimene, vaid autojuht.

Asjast sai politseile teatatud, ning juhusel, kui asi kordub võetakse mees ulakuse eest vastutusele. Seekord õnnestus aga "kangelasel" haihtuda (ELS 4/1936: 201).

Kaitstud polnud linnades ka teised linnud. 1935. aastal võitlesid Kuressaare aiapidajad kuldnokkadele pesakastide ülespanemise vastu, kartes marjasaagi pärast. Lindude vastased leidsid, et 8000 kuldnokka 1000 pesakastis on väikese linna kohta liiga palju. Lindude advokaadid selgitasid, kuidas kuldnokad hävitavad viljapuudele kahjulikke putukaid, saades seega moraalse õiguse osale saagist. Linnuvägivalda siis ka ei rakendatud, asjas osalenud inimesed jõudsid kokkuleppele (anonüümne artikkel "Sõjakäik kuldnokkade vastu Kuressaares” - ELS 2/1935: 35). Hullem oli olukord Tallinna lähistel Kadaka teel, kus majaomanik L. ei sallinud pääsukesi ning käskis lõhkuda juba koorunud poegadega pesad:

Pesad äsja munakoorest väljunud linnupojukestega paisati maha. Õhus lendlesid aga heleda hädakisaga vanad pääsukesed. Inimesed vaatasid ja avaldasid meelepaha. Üteldi, et kui 


\section{Loone Ots}

ei sallita pääsukesi, siis oleks võidud vähemalt nende pesad lõhkuda juba varem, kui munad alles koorumata. Siis poleks hävitamispilt olnud nii masendav.

Tallinna loomakaitse seltsi poolt esitati politseile kaebus majaomaniku vastutusele võtmiseks (ELS 4/1935: 72).

See tegu sai karistuse:

Kohus karistas toorest peremeest, kui ka sulast igaühte 10kroonilise rahatrahviga või 3-päevase arestiga (ELS 2/1936: 164-165).

Huvitaval kombel on vähe teateid tänaste kõige levinumate ohvrite, kasside kohta. Ainult Eesti Loomasõbra 1937. aasta märtsinumbris leidub nupp, mille kohaselt lõikasid Rakvere poisikesed elusal kassil keele suust, nii et vaevlev loom tuli hukata. Süüdlased selgitati välja, nad tunnistati süüdi ka kasside ja lindude laskmises ragulkadega. 1936. aastal toob Tartu loomakaitsja A. Tschertkoff oma artiklis "Me tahame sammuda edasi" mõned näited kasside piinamisest, võrreldes tagajärgi analoogilise olukorra tagajärgedega inimühiskonnas:

7-aastane poisikene endale meeleheaks torkas kassipojal naelaga mõlemad silmad välja, ja kui meie pöördusime tema ema poole, siis ema naeratades mainis: "See on ju ainult kassipoeg, loom." Millist õigustatud protesti oleks tõstnud kogu ajakirjandus, kuidas kogu politsei kaader oleks tööle rakendatud, kuidas oleksid kohtunikud ja advokaadid astunud üles, kui oleks nii toimitud lapsega... Autor on ise pidanud nägema, kuidas poisikesed, pü̈̈des kasse nende nahkade mü̈̈giks, ei lasknud neil lõplikult surra enne nülgimist (Tschertkoff 1936/ 1:174).

Õnneks puuduvad 1930. aastaist vähemalt teated tänapäeval tõsiseks probleemiks olevate kasside kallal sooritatud rituaalmõrvade kohta.

Kõige markantsem loomavastane kuritegu oli seotud koertega ja selle antikangelane oli seksuaalhälbega noormees, kes kastreeris kahe aasta jooksul Nõmmel koeri ning kui politsei uurimistöö tulemusel polnud seal enam võimalik tegutseda, kolis oma tegevuse Harjumaale, kus ta viimaks ka kinni võeti ja kaheks aastaks vangi mõisteti (ELS 1/1936: 143; ELS 4/1937: 316). 


\section{Positiivseid näiteid}

Inimese ja hobuse suhe oli nähtavasti kõige lähedasem. Kõrvuti jubedate lugudega julmustest hobuse vastu loeme just nende kohta ka palju toredaid näiteid; osalt seostub hobuse eest hoolitsemine kindlasti ka tema ajaliku väärtusega. Vahvaim lugu kannab pealkirja "Hobusele tehti vihusauna":

Jõhvi valla Kohula küla talupidaja J. Kurba oli ostnud endale uue hobuse ja tulnud sellega koju $60 \mathrm{~km}$ pikkuselt teekonnalt. Kuna teed olid kõrgetes hangedes ja osalt ka lumest paljad, siis väsis hobune pikast sõidust sedavõrd, et ta kodus jalgu enam alla ei võtnud. Talupidaja küttis nüüd vihusauna soojaks, vedas hobuse sisse ja tegi loomale päris korraliku sau-

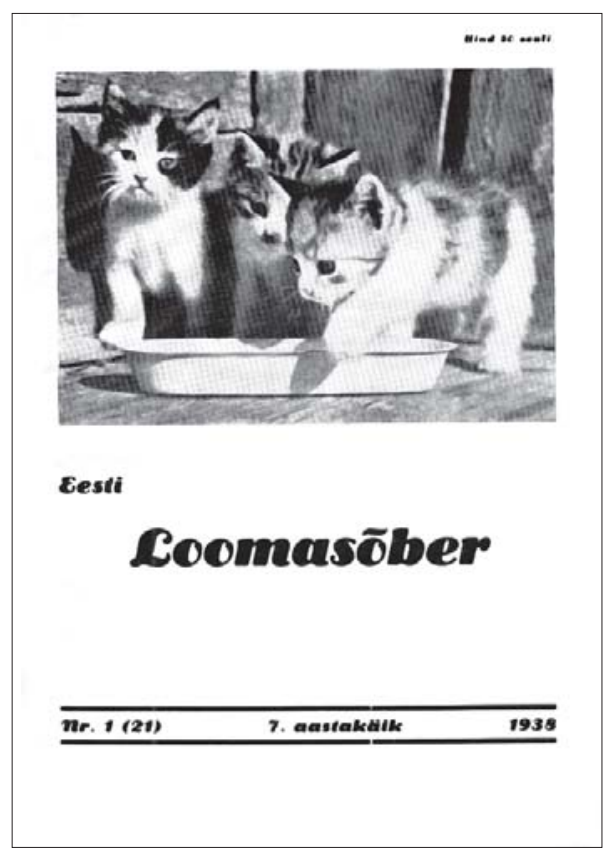

Joonis 3. Mis võiks olla veel positiivsem ja paeluda loomasõbra pilku paremini kui armsatest kiisupoegadest "kaanetüdrukud"? 
Loone Ots

na. Ta vihtles ja leilitas hobust seni, kuni loom võttis jälle jalad alla ja osutus täitsa terveks (ELS 1/1937:262).

Austust ja armastust paljupiinatud kodulooma, ikka sellesama hobuse vastu väljendab järgmine teade:

Haimre valla peremehel J. L.-l suri hiljuti 39 a. hobune. Peremees lubab istutada pika eluseltsilise hauale mälestustamme (ELS 2/1937: 281).

Ka eelmainitud Mustvee annab vähemalt ühe positiivse näite: hobuste elusalt nülgimise kirjeldus lõpeb mažoorse noodiga kohaliku loomakaitse edenemisest ja selle praktilisest kasust:

Mustvee kõrgema algkooli juures kutsuti ellu loomakaitsering, kuhu õpetaja pr. E. Linde eestvõttel on koondunud juba 70 liiget. Opilased on lindude jaoks juba üles seadnud söömalauad.

Üks 8-aastane õpilane tegi etteheiteid maamehele, et see peksis hobust, kes ei jõudnud lumest paljal teel vedada rasket koormat. Mees oli lapse sõnadest üllatatud, loobus hobuse löömisest ja ladus kohe pool koormat reelt maha (ELS 3/1935: $54)$.

Heade uudiste hulka võib liigitada ka loo alpi kaljukotkast, kes tormist väsinult laskus Eesti tulelaeva pardale. Kotkas ei kartnud inimesi ja ta paigutati vastloodud meremuuseumi. Kuid

[---] kuninglik lind ei leppinud vangipõlvega [---] ta ei võtnud puuris olles mitmel päeval enam toitu, kuigi temale puuri pandi isuäratavaid lihatükke. Oli näha, et kotkapoeg ennem nälgib surnuks, kui et jääb elama kitsasse puuri. Seepärast otsustati lind lasta vabadusse. Merikapten Mey ja insener Wieckmann tõid linnu puurist välja ja lasksid ta lahti. Kotkas lehvitas võimsaid tiibu ja võttis otsekohe suuna $N$-W põhja-lääne poole (ELS 1/1935: 11).

\section{Loomakaitsjate rahvavalgustustöö}

\section{Kirjutised Eesti Loomasõbras}

Haridustöö sisaldas peamiselt juhiseid, kuidas hoolitseda teatud liiki loomade või lindude eest, samuti käsitleti tänuväärselt võima- 
lusi, kuidas tappa loomi toiduks neile võimalikult vähe kannatusi põhjustades. Tutvustati mitmesuguseid loomi (bernhardiin, orav, põhjapõder), linde (Vilsandi linnud) ja kalu ning teisi veeloomi (Eesti kalaliigid, konnad, krabid), sealhulgas neid, kelle suhtes inimestel on kujunenud eelarvamusi (kuldnokk, kes ei ole sugugi nii suur marjade vaenlane, kui inimene usub - vt Tonson 1935; anonüümne artikkel "Kärnkonn" ELS 4/1935: 66).

Mitu artiklit ilmus kassi kohta. ELS püüdis kummutada ka mitmeid kassiga seotud eelarvamusi, nõudes, et kassi nagu koeragi toidetaks ja õpetataks. Anonüümne kirjutis "Meie hiirtekuningas. Kuidas hoolitseda kodukassi eest" ütleb selgelt:

Kui kassi peetakse koduloomana, kellelt tahetakse tulu saada, siis tuleb ta eest ka hoolitseda [---] Kass murrab hiiri ja rotte röövimishimust aetuna ka siis, kui ta ei ole näljane [---] nagu igat looma, saab ka kassi kasvatada [---] (ELS 3/1937: 298299).

\section{Kolm näidet loomakaitseseltside tegevustest}

ELS püüdis igas numbris tutvustada üht või mitut kohalikku loomakaitseseltsi. Ajakirjast saab teavet seltside asutamise aja, liikmete arvu ja elukutsete, seltside tegevuste ja nende tagajärgede kohta.

Tallinna Loomakaitse Selts. Vanim (asutatud 19. sajandi lõpul) ja liikmete arvult suurim (475 liikmemaksu maksnut 1935. aastal, tegelik liikmeskond veel suurem, sest selts kaebas, et osa liikmeid ei ole maksu tasunud) oli Tallinna Loomakaitse Selts, mille tegevus oli väga mitmekülgne. 1935. aastal esitati neli suuremat (ja investeeringuterohket) nõudmist, mis kõik täideti: keelata linna eksporttapamajades loomade tapmine eelneva uimastamiseta; nõuda eksporttapamajalt Estonia haruraudtee ehitamist Ülemiste jaamast otse tapamaja hooneteni, vältimaks loomade mahalaadimisel ja ajamisel ettetulevat piinamist; selgitada loomakaitse põhimõtteid ja vastavat seadusandlust politseikoolis ning nõuda postil olevatelt politseinikelt rohkem tähelepanu loomapiinamise juhtumiste suhtes; mitte lubada rändloomaaedadel loomi eksponeerida ilma nendele sobivate ruumideta ja nõuda hetkel Tallinnas tegutseva loomaaia likvideerimist. 


\section{Loone Ots}

Palju tööd tegi Tallinna loomakaitse hüljatud ja loovutatud loomadele uute kodude leidmisel. 1934. aastal toodi seltsi varjupaika 38 leitud koera ja omanikud loovutasid varjupaika 202 koera. Viis koera tuli haiguse tõttu surmata. Et 290 isikut soovis varjupaigast koera saada, pidid paljud leppima kohaga ootejärjekorras. Kasside käsi käis siis, nagu nüüdki, halvemini: aasta jooksul soovis ainult viis inimest endale kassi saada, seetõttu tuli hukata ülejäänud 107 peremeheta kassi.

Lisaks arutas loomakaitse esitatud kaebusi, edastas neid politseile, käis kohal, tegi suuliseid ja kirjalikke hoiatusi. Kokku arutas loomakaitse 135 pöördumist, millest politsei sekkumise vääriliseks peeti 17.

1935. aastal olid suhtarvud umbes samad: 270 inimest soovivad koera, seltsi varjupaika oli toodud 40 leitud koera, veel 19 koera oli olnud inimeste juures "kasuperedes", omanikud on ära andnud 151 koera, niisiis oli selts saanud anda koera 210 soovijale. Kasse olid soovinud vaid mõned üksikud, mistõttu 109 kassi uinutati. Kaebuste arv oli suurenenud ja 207 kaebusest jõudis politseini juba 27.

1936. aastal jäid koerte suhtarvud enam-vähem samaks: 310 inimest soovib koera, 45 koera leidis selts, 73 koera hoidsid enda juures eraisikud, peremehed loovutasid 164 koera, kaks haiget koera surmati, seega anti loomakaitse kaudu uude koju 280 koera. Kahjuks pole ühtki märkust väljastatud kasside kohta, kuid 183 kassi kaotab elu. Uudisena oli varjupaika saanud ka üks öökull, neli kodutut lindu(?) ja kaks kanaarilindu. Lisaks oli varjupaigale mü̈̈a pakutud ahvi. Kaebusi oli 215, nendest anti politsei menetleda 23.

Viimase tegevusvaldkonnana võib märkida Tallinna loomakaitsjate (ja ametlikult kogu ELLi) algatust lubada koertega reisijaid Tallinna ühissõidukitesse, eeskätt põhilisele liiklusvahendile trammile. Soov esitati korduvalt. Kuigi palvet toetasid jahimeeste seltsid ja Kennelklubi ning ELL esitas näiteid kõigi Euroopa suurlinnade praktikast, ei andnud linnavalitsus koerte trammis sõiduks luba. Hiljem said koerad ainult bussisõiduõiguse.

Viljandi Loomakaitse Selts. Võrdluseks võib tuua näite maakonnakeskuses Viljandis töötanud loomakaitseseltsi tegevusest. Selts asutati 1929. aastal. 1930. aastail juhtis seda linnaveterinaar ja tapamaja juhataja $d r$. vet. Friedrich (hiljem eestindatult Vidrik) Saar. Selts ühendas umbes 80 peamiselt intelligentsi hulka kuuluvat vil- 
jandlast. Avaldati artikleid ajakirjanduses, Mulgimaa künklikele teedele seati üles nn hobusepalved, mis palusid peremehi rasketel tõusudel vankrilt lahkuda, jne.

1934. aastal loodi Viljandisse "loomade valuta surmamise punkt", kus sümboolse tasu eest sooritati eutanaasia loomaarsti järelvalve all. Selts kontrollis aktiivselt turge; et liikmeil on seda leivatöö kõrvalt raske teha, tegi selts 1936. aastal ettepaneku luua Viljandisse spetsiaalne loomakaitseinspektori ametikoht.

Aasta varem tegid viljandlased ELLile ettepaneku anda välja raamat loomakaitsealaste küsimuste selgitamiseks. Rahapuudusel ei saanud üllitisest nähtavasti asja, kuid ELL lubas saata pädevaid lektoreid kõnelema mis tahes Viljandi loomakaitsjaid huvitaval teemal. Selle projekti raames sõitis Viljandisse nt ELLi abiesimees A. Tamm, kes pidas pidulikul aktusel kõne loomade ja inimese hingelisest lähedusest. Kõne sõnum põhines kahel teesil: kui meil on õigus rääkida kõrgemast kultuurist, siis ainult selles mõttes, et meie elu teotsemise programmis ei tohi puududa loomakaitse; teiseks, noorsugu tuleb kasvatada armastuses mitte ainult loomade, vaid terve looduse vastu - ilusad mõtted, mis täie kindlusega kehtivad ka tänapäeval.

1939. aastal korraldas Viljandi selts taas loomakaitsepäeva, mille raames peeti Koidu saalis aktus, kinodes näidati "päevakohast valgusreklaami”, levitati brošüüre (niisiis said need ikkagi trükitud!) jne (ELS 3-6/1939: 11).

Seltsi tegevust tunnustas ELL II klassi Rohelise Risti annetamisega nii V. Saarele kui abiesimees J. Tilkile. Esimesel jäi loomade aitamiseks veel vähe aega: põrandaaluse nõukogudevastase tegevuse eest arreteeriti kolme väikese lapse isa V. Saar 1941. aasta suvel ja mõisteti 1942. aastal Jaroslavlis surma mahalaskmise läbi. Troika võimaldatud lõppsõnas kinnitas V. Saar püstipäi, et tegutses nõukogude võimu vastu täie teadmisega ja teeks seda jälle, sest usub, et Eestil on punaselt võimult oodata vaid kannatusi. Nii jäi hingestatud loomakaitsja oma kord valitud aadetele ustavaks elu kõige raskemal hetkel, mis tõestab, et ta oli kõrge eetikaga inimene, kes oli valmis vajadusel andma elu oma põhimõtete eest.

Petseri Loomakaitse Selts. Riigi ääremail asuvat mitmekultuurilise asustusega Petserimaad peeti 1930. aastail arhailise elukorraldusega mahajäänud piirkonnaks. Loomakaitse korralduse poo- 
Loone Ots

lest polnud lugu aga kaugeltki halb. Petseri Loomakaitse Selts tegutses aastast 1927 ja viis läbi loomakaitse sundmääruse kehtestamise Petseri linnas (mida nt Viljandis suudetud teha). 1936. aastal on Petseri seltsil 120 liiget, tegutseti nii linnas kui ka maakonnas.

Seltsi üks peamisi ülesandeid oli jälgida Petseri kuulsat hobuselaata ja konfiskeerida parisnikelt naelte ja tinaplommidega varustatud piitsad, mille löögi abil taheti loomi erkudena näidata. Väga hea oli koostöö kohaliku veterinaariga, kes ravis vaeste inimeste loomi maksuta - sel juhul tasus loomakaitse vajalike arstimite eest. Tänu seltsi liikmele sepp J. Säägile on asutatud eeskujulik sepikoda, kus hinnad olid väga mõõdukad, mistõttu klientuuripuudust polnud karta. Kohalikud kasutasid meeleldi sepikoja teenuseid, kuid pidasid seda arsti olemasolu tõttu ekslikult Punase Risti asutuseks.

Lisaks aktustele ja lendlehtede levitamisele tegi Petseri loomakaitse muudki vajalikku, vedades nt talvel päikesepoolsetele künkanõlvadele lund, et aidata raskeid koormaid vedavaid hobuseid.

\section{Kokkuvõtteks}

1930. aastail oli loomakaitse Eestis jõud, mille liikmetel oli arvestatav positsioon ühiskonnas. Samas ei olnud loomade väärkohtlemine ning loomadele suunatud julmus ja vägivald haruldane ei linnas ega maal.

Maal esines peamiselt hobuste ja tapamajja viidavate kariloomade peksmist, hobuste ülekoormamist ja hooletusse jätmist, vägivallajuhtumid olid seotud alkoholi pruukimise ja utilitaarse suhtumisega; massiliselt esines salaküttimist.

Linnas olid mured seotud voorimeeste hobustega, kuid olukorda parandasid kohalike omavalitsuste sundmäärustega kehtestatud nõudmised, mille täitmist loomakaitse kontrollis. Linnades tuli ette rohkem linnupesade hävitamist, loomade mõnitamist ja sandistamist.

Paljud nimetatud juhtumitest jõudsid tänu loomakaitsjaile kohtusse ja loomavägivald sai seadusega ettenähtud karistuse. Ajakirjas Eesti Loomasõber avaldatud materjalide põhjal hõlmas loomakaitseseltside tegevus põhiliselt põllumajandus- ja traditsiooniliste 
lemmikloomade olukorra parandamist, millega seoses tehti rahvaharidustööd loengute ja teavitavate trükiste kaudu, kontrolliti turge, laatu ja majapidamisi loomapidamistingimuste osas, töötati välja ning esitati omavalitsustele kehtestamiseks loomi kaitsvaid õigusakte ja üllitati juba nimetatud ajakirja, mis lisas eesti loomakaitsele ka rahvusvahelise mõõtme. Tallinnas oli hästi toimiv kodutute koerte ja kasside varjupaik; maakonnalinnades avati eutanaasiapunkte, õige rautamise töökodasid jm.

\section{Kirjandus}

Ambrosi, Harkovi ülempiiskop (= Kljutšarov, Aleksei Jossifovitš) 1901. Õpetus lastele, kes külakoolides käivad: Loomadega peab tasaselt ja haledameeleliselt ümberkäidama = Наставление детям, учащимся в сельских школах: О кротком и жалостливом обращении с животными. Riia: Paltimaa Õigeusu Vennasteselts \& Riia Peetri-Pauluse Vennaste-selts.

Eesti Loomasõber. Eesti Loomakaitsjate Liidu ajakiri 1935-1939.

Haridus- ja sotsiaalministeeriumi Teataja 11. 1933.

Kattemaa, Arnold 1935. Inimene ja loom. Eesti Loomasõber 3, lk 47.

Lind-af-Hageby, Louise 1935. Kas peame olema mitmekülgsed? Eesti Loomasõber 2, lk 23-24.

Loomade ja loomatoorsaaduste veomäärus 1925. Riigi Teataja 149.

Loomade ja loomatoorsaaduste veomäärus muutustega 1931. Riigi Teataja 103.

Matto, August (?) 1935. Kuhu suundub inimsugu? Loomakaitse ülesandeks on inimsoo hinge äratamine. Eesti Loomasõber 1, lk 4-5.

Methusalem, Bernhard 1936. Loomakaitse aade saagu ilmavaateks. Eesti Loomasõber 1, lk 127.

Mieler, A.(?) 1920. Kas vajavad loomad ja taimed inimese kaitset? Tartu Eesti Loomakaitse Ühing: Lendleht. Tartu: Tartu Eesti Loomakaitse Ühing.

Noor, Saima (koost \& toim) 1993. Eesti A ja O: [Üldentsüklopeedia]. Tallinn: Eesti Entsüklopeediakirjastus.

Tallinna... 1891 = Tallinna "Elajakaitse-Seltsi" lennuleht Eestirahvale 1. Tallinn: s.n.

Tonson, A. 1935. Kuldnokk. Eesti Loomasõber 3, lk 50.

Tschertkoff, A. 1936. Me tahame sammuda edasi. Eesti Loomasõber 1, lk 175-176. 